\title{
African Humanism as a Basis for Social Cohesion and Human Well-Being in Africa
}

\author{
Obioha, Uwaezuoke Precious, Phd \\ Department Of Philosophy, Akwa Ibom State University \\ Obio Akpa Campus, Akwa Ibom State, Nigeria \\ Godwin Okaneme, Phd \\ Department of Philosophy, University of Abuja \\ Abuja, Nigeria
}

\begin{abstract}
Africa is confronted with challenges of social unrest such that many years after independence of most African nations much has not changed in the socio-humanistic experiences of Africa and Africans. The importation of some extraneous ideologies and institutional interventions on Africa to serve as solutions has successfully failed. This perhaps accentuates the irrelevance of imposing certain western categories on African problems. But this confirms the wisdom that "our philosophy must find its weapons in the environment and living conditions of the African people". African culture and identity is therefore relevant in fashioning a solution(s) to African problems. One of such solutions is African Humanism which is an important constituent of African culture. The paper employs the analytic and critical methods of philosophy to show the richness and the dynamics of African Humanism in minimizing the challenges of social unrest and enhancing the general human well-being of Africans. African Humanism expresses strong distaste for extreme individualism, unnecessary competitions and personal enrichment that characterize governance in the continent of Africa. African Humanism also favors a community-based society which amplifies the virtues of social well-being and solidarity which is conducive for social justice. With its theistic ethos, African Humanism brings with it the spiritual dimension that complements and satisfies man's spiritual needs and helps people treat others as God's images like themselves. The paper believes that a successful blend of these three aspects of African Humanism will help in the actualization of life's aspirations both for the individual and the community at large.
\end{abstract}

\section{INTRODUCTION}

When the definition of the African problematic became necessary, many different forms of definitions were offered. One of such definition was hinged and blamed on colonization. This is aptly captured in Nkrumah's assertion that,

...the whole solution to this problem (colonization) lay in political freedom for our people, for it is only when people are politically free that other races can give them the respect that is due to them. It is impossible to talk of equality of races in any other terms. No people without a government of its own can expect to be treated on the same level as peoples of independent sovereign states. It is far better to be free to govern, or misgovern yourself than to be governed by anybody else. (Nkwumah, 1957:vi).

This appeared to have provided the rationale for the anti-colonial struggle of the 50s and $60 \mathrm{~s}$. But unfortunately, socio-political and economic situations in Africa immediately after independence and more apparently now have confirmed that political independence has not secured for Africa the much desired self-respect, equality, development and human well-being. Someone may ask, is it not better to be governed by foreigners and you live a better life than to govern yourself and live in disaster?

Today Africa is certainly confronted with challenges of social unrest, general human life abuses and frustrations such that many years after independence of most African nations, much has not changed in the socio-humanistic experiences of Africa and Africans. Poor governance or bad governance and ineptitude leadership have become synonymous with most African states. Today, there is wide spread 
belief that Nigeria is broke and bankrupt with more than 20 out of the 36 states of the federation unable to pay workers' salaries running to months. "This is a shame", as stated by the present president of Nigeria - Muhammadu Buhari even as he alleges that he inherited an empty treasury with debts amounting to billions of dollars from the previous administration and therefore the immediate expectations of Nigerians from his administration may be farfetched.

Within the present African Cultural Matrix, we perceive a widespread anthropological ignorance, outright cultural apostasy; bizarre and baffling misplacement of values and accordance of recognition, and the fertile gestation of the triplets of the good, the bad and the ugly, coming to life in a mutual terminal opposition. The picture of this race as painted here reveals the appalling degree of the present lives the African people, their ignorance about themselves that has largely characterized their almost rudderless performance as a people in the context of the comity of nations. This situation calls for a serious attention and not a pretentions socio-cultural window dressing as being witnessed today in most African states.

If indeed the end of colonization was not liberation for Africa, what then is? What should Africa and Africans be doing or must do to usher in African renaissance? We may have to take our destinies in our hands. The African socio-cultural world, like any other, may well be like a ship of which the set of the sail decides the way it goes, and not the calm or the strife of the sea. This is how Ella Wheeler Wilcox captured the fate of such a world;

One ship drives east, and another West with the self-

same winds that blow:

"Tis the set of the sales

And not the gales,

which decides the way to go...

...And not the calm or the strife.

The solution to our quagmire and problematic may not be based, after all, on various extraneous ideologies and institutional interventions because most of such extraneous ideological and institutional interventions have actually failed us as a people. This perhaps accentuates the irrelevances of imposing certain Western categories on African thought systems and problems. But this confirms the wisdom that "Our philosophy must find its weapons in the environment and living conditions of the African people". African culture and identity (albeit selectively) is therefore relevant in fashioning a solution(s) to African problems. One of such solutions is found in African humanism which is an important constituent of African culture.

As identified in this paper, African humanism stands on tripod values. First, it expresses strong distaste for extreme individualism which could fan the flames of unhealthy and unnecessary competitions and intrapersonal conflicts, personal aggrandizement and enrichment that characterize governance in the continent of Africa. Second, African humanism also referred to as African socialism or African communalism favours a community-based society which amplifies the virtue of social well-being, synergy, solidarity, cooperative togetherness, interdependence and reciprocal obligation which is conducive for social justice. Third, with its theistic ethos, African humanism brings with it the spiritual dimension that complements and satisfies man's spiritual needs and longings and helps people treat others as God's images like themselves and not as mere objects.

The paper argues that a blend of these positive values will provide practical consequences that will concretize the reality of wholesome human relationship which is necessary for the actualization of life's aspirations both for the individual and for the community at large.

\section{AFRICAN HUMANISM AND EXTREME INDIVIDUALISM}

One of the current vices or features plaguing our modern society is radical or extreme individualism. The theory of individualism holds that the welfare of the human community is best secured by allowing every person the widest scope of liberty consistent with the freedom and safety of others (Readen, 1973:5). In other words, individualism carries a belief that the right of the individual members of the community is better guaranteed when every individual is afforded an equal liberty and freedom to do his normal business in accordance with the dictates of his or her conscience. In this system, the role of the community is merely to "guide" the freedom for individuals and to provide them with needed security and to maintain order. The community is not to interfere with the activities 
of the individual themselves. This kind of philosophy upholds that every person as a discrete entity should be allowed and left free to manage his life, his properties, his economic affairs as he deems fit and appropriate. According to Herbert Spencer, one of the most outstanding proponents of the theory of individualism opines that there is going to be much progress in society when individuals are permitted to work out their own destiny without governmental regulation or assistance. Spencer argues thus:

It seems hard that a labourer incapacitated by sickness from competing with his stronger fellows, should have to be the resulting privations. It seems hard that widows and orphans should be left to struggle for life or death. Nevertheless, when regarded not separately, but in connection with the interests of universal humanity, these hard fatalities are seen to be full of the highest beneficence (Schmandt, 1956:132)

The implication of the above reasoning of Spencer is that only the fit in the society will survive. What beneficence is foreseen in this other than the extreme enjoyment of the 'fit' at the detriment of the "weak"? According to Chukwuemeka Ekei $(2001,145)$ there is a denial of moral justice in this form of individualism coupled with a question of unpredictability of human fortune, today and tomorrow. Therefore, in the context of human predicament, fraught with limitations, powerlessness, scarcity, inequality and ambivalence, the principle of individualism will hardly offer any meaningful solution, neither can it favour the cause of the less privileged; not where the fittest have greedily replaced their positions.

The philosophy of excessive individualism is a philosophy of "No limits" to man's freedom and autonomy to decide and create values by which he/she lives. In excessive individualism there is nothing like social values or social norms that bind individual members of the community together and under which actions and behaviours are accepted or rejected. Individuals are free to break rules that seem to limit their freedom to do as they wish and consequently free to evolve rules and values that expand their freedom to live as they wish. In the bid for people to live as they wish, extreme individualism could and does fan the flames of unhealthy and unnecessary competitions and intrapersonal conflicts. Also, extreme individualism as seen in Africa today amongst our leaders is responsible for fanning the ambers of personal aggrandizement, self enrichment and high levels of political corruption that characterize governance in the continent of Africa and indeed every facet of our lives as a people. If not, how can one explain this habit of looting public treasury, for one's personal gains, that characterize most African leaders and public office holders?

The reason is that they are thinking personal and not collective. They are not thinking about 'the people'. They are not thinking 'ujamaa'; they are not thinking "Ubuntu". To think ujamaa and Ubuntu is to think communally - to be community-oriented in one's thinking, attitude and dispositions. The philosophies of ujamaa, ubuntu etc break the backbones of envy, unhealthy competitions, revenge and punishments but rather seeks, unity, reconciliation and friendship.

African humanism is identified with movements of national independence and with the development of collective African identity. The more political side of it is referred to as African socialism. According to Richard Bell (2002:37) both African humanism and socialism were used to underscore the values of a common African heritage and the inherent struggle left to a people who were exploited by colonial powers. Nkrumah opines that African socialism was more in tune with the original humanist principles underlying African society (Nkrumah, 1964:70) Nyerere said: "Ujamaa", then... describes our socialism". "Our socialism", is the recognition of society as an extension of the basic family unit; it was an attitude of mind for Nyerere that reaches back to "tribal days". But, he says, the family to which we all belong must be extended yet further - beyond the tribe, the community, the nation or even the continent - to embrace the whole society of mankind. This is the only logical conclusion for true socialism (Nyerere, 1968: 12). Kwame Gyekye succinctly captures the meaning of African humanism when he defines the concept of African humanism as follows, "a philosophy that sees human needs, interests and dignity as of fundamental importance and concern. For, the art, actions, thought, and institutions of the African people, at least in the traditional setting, reverberate with expressions of concern for human welfare" (Gyekye, 1997: 158). This philosophy extols the virtues of a community-based society which recognizes certain "self-interest" among men and women but that self-interest is subordinated to communal well-being. 
In his short article titled, "Ubuntu: Something our society needs" Donald Demarco opines that Ubuntu which rejoices in the achievements of others, is the antithesis of envy (occasioned by individuals thinking only about themselves), which broods over them. The word Ubuntu originates in the Bantu language of Southern Africa. The short hand definition is: "I am because we are". A slightly longer version is: "I am what I am because of who we all are".

On the other hand, it is apt to say that Descartes (father of modern philosophical thoughts in the western world), whose deathless phrase, "I think therefore I am", is perfectly congruent with the radical individualism that is plaguing our current society. This view has trapped us, to borrow the words of the American philosopher Ralph Barton Perry, in an "egocentric predicament". African humanism underscores the philosophy of personalism which described the human being as simultaneously a unique individual and a responsible member of society manifesting the virtues of sympathy, love, care and concern for others. African humanism is rather opposed to radical or extreme individualism and all its specific incarnations: the self-made man, the self-reliant individual, the rugged individualist, numero uno, the egoist, the fortune hunter, the gold-digger, and all those who seem to live by Oscar Wilde's aphorism, "other people are quite dreadful. The only possible society is oneself". This is counter-productive to social cohesion and human well-being. No society truly survives on the pangs of selfishness, self-centeredness and extreme individualism.

\section{AfRican Humanism: A COMmunity-BASEd Society}

An integral part of African humanism and socialism is communitarianism simply understood as a community-based society. This idea is derived from the African concept of communalism. According to Gyekye (1987:155) "Communalism may be defined as the doctrine that the group (that is, the society) constitutes the focus of the activities of the individual members of the society. He further states that the doctrine places emphasis on the activity and success of the wider society rather than, though not necessarily at the expense of, or to the detriment of the individual". This shows that communalism is a doctrine about social organizations, relations and net-workings and is therefore an offshoot of the African concept of humanism. African humanism constitutes all human beings into one universal family of humankind having the same Father God. This idea is expressed by an Akan Maxim. "All human beings are children of God; no one is a child of the earth".

This claim is based on the belief that there must be something intrinsically valuable in God: the human being considered a child of God, presumably by reason of having been created by God and having in his or her nature some aspect of God, ought also to be held as of intrinsic value, worthy of dignity and respect. The general African belief that human beings are created by God - that they are children of God - most probably lies at the base of the values attached to humanity and unity by the African people. And their having a speck of the divine nature (i.e. soul) in them constitutes all human beings into one universal family of humankind (Gyekye, 1996). The idea of one universal human family is the idea of human brotherhood. Communal personhood is therefore the idea that the human person has a natural sociality that defines his being. That relationality (sharing in a network of relationships) is what constitutes the human person. This means that man is a social animal.

Aristotle proclaimed many centuries ago that man is by nature a social animal and that it is impossible for him to live outside society. African thinkers (Gyekye, 1996, Wiredu, 1983, Gbadegesin, 1991, Iroegbu, 2000) all agree that society is not only necessary condition for human existence, but it is natural to man. Gyekye (1996:36) believes that this idea is expressed in an Akan proverb which says:

When a man descends from heaven, he descends into a human society.

In descending into a human society, the human person does not live a solitary and uncooperative life (the type that characterizes Hobbes' state of nature. This is itself a rejection of the concept of the state of nature, as explicated by Hobbes and other eighteenth-century European philosophers who asserted the existence of an original pre-social character of man) but from the outset is involved in an intricate web of social relationships with other humans in the society.

So said, what is the basis for this idea of the community? The idea of the dignity and the well-being of the human person lie in the answers to this question. So the consequences of this African idea of communalism are the spring board for the dignity of the human person and consequently human wellbeing. Human life is characterized by adventures, ambitions, dreams, desires and aspirations. This is a truism. But of no less truth is that human life is equally characterized by weaknesses, frustrations, hindrances, limitations and failures. However, these limitations and frustrations can be overcome. One 
observation from life's (Africans') experiences of limitations and sufferings is the fact contained in the Akan and Igbo maxims respectively: "A human being needs help", "I am my brother's helper".

Being a normative (moral) statement the maxims express just more than a fact about human life or the human condition. The real meaning is that a human being deserves and therefore ought, to be helped. This also means that a human being must be regarded as an object of moral concern that is entitled to help. But such moral concern can hardly be demonstrated when human beings live a solitary life, in isolation from, and without enjoying the fellowship of other human beings as a result of greed, envy, selfishness and self-centeredness occasioned by extreme individualistic tendencies.

The necessity of human fellowship for the well-being of the individual human being is stressed in the following Igbo proverb: "It is a human being that is needed (mmadu ka eji aka)". In order to overcome or not to be overwhelmed by life's challenges, human fellowship can be a basis for all kinds of help an individual may want or need. But human fellowship is constituted only by human beings, hence, their worth, as affirmed in the following maxims.

When an animal needs to scratch its back, it runs to a tree and scratches its back against it; but when humans need to scratch their back, they run to fellow humans. It is the human being that counts; I call upon gold, it answers not; I can upon cloth, it answers not; it is the human being that counts.

So man needs his fellow humans in order to overcome his life's challenges. Life's ambitions and aspirations are better and easier achieved in a cooperative environment. Individual capacities are insufficient to meet basic human requirements. A person proverbially is not a palm tree that he or she should be complete or self-sufficient. Therefore, the individual inevitably requires the succor and the relationships of others in order to realize or satisfy basic needs and attain his dreams and aspirations. This fact is expressed in these Akan, and Igbo proverbs which states that:

The prosperity (or well-being) of man depends upon his fellow man. (Obi yiyefiri obi). (Akan)

One finger cannot lift up a thing.

If one man scrapes the back of a tree for medicine, the pieces fall down.

The left arm washes the right arm and the right arm washes the left arm. (Aka ekpekwuo aka nri, aka nrikwuo aka ekpe). (Igbo)

So, in the communal social order, material and other benefits are more likely to be available to all the members of the society than in an individually-structured society. The reason is that the communal social order is participatory and other-mindful, and that it is characterized by such social and ethical values as social well-being, solidarity, interdependence, cooperation and reciprocal obligation. According to Gyekye, all of these conduce to equitable distribution of the resources and benefits of the society to the fulfillment of individual aspirations and indeed communal well-being (Gyekye, 1996). However, a critic may argue that if communalism is this wonderful, why have we been having some social conflicts and problems in Africa? Our answer is that the cases of social problems in Africa do not in any way negate the virtues of communalism. Social problems are inevitable giving the ambivalence of human nature. Human nature is not the same, so human beings do not act in the same way. No matter how pristine any communal ethic may be, there is bound to be dissents and deviants- those who will do everything and anything to disrupt it and for the fact that they do succeed in disrupting it does not discredit such ethic. Therefore, African philosophy of communalism remains valuable for social cohesion and well-being. Again the fact that Africa is faced with all kinds of social unrest today is a testimony and pointer to the fact that Africans have lost or jettisoned this virtue in their unguided patronage to modernity. Therefore, there is the need to reinvent this virtue.

So the values of social well-being, solidarity, interdependence, cooperation and reciprocal obligation etc. provides the basis for the philosophy upon which the African concept of communalism rests.

\section{African Humanism: its SPIRITUAL Dimensions}

African humanism is heavily theistic. African (theistic) humanism encapsulates their beliefs about man, God and the universe. Africans are deeply spiritual people and believe that God created the universe and all that is in it including human persons. To Africans generally, there is a personal God and his divine spirit is the life force that permeates all things in the universe. The traditional Igbos of 
Nigeria, for instance, are said to be ontologically religious. According to Major Leonard, the traditional Igbos were "a truly and deeply religious people of whom it can be said, as it has been said of Hindu, that they eat religiously and drink religiously"(Ekwuru, 1999:94). This is also true of all Africans.

The virtue of African theistic humanism does not lie so much on the fact that Africans are incurably religious, but rather on the fact that they believe in God's existence and the fact that their fellow humans are God's images like themselves. These two-fold virtues have a way of impacting positively on human existence, social cohesion and human well-being.

God is at the center of man's life and the universe and therefore any life outside God or any attempt to understand man outside God or to understand the universe fully outside God will end up in meaninglessness and futility. And when life ends in futility and meaninglessness, it loses its dignity and essence. Any attempt to banish God from human existence is problematic. And this is one of the problematic of secular humanism. The problem with humanism is not really whether God exists or not. The problem is the banishment of God, by humanists, from human existence and experiences. The humanists claim that man has no need of God in his life, that God holds no relevance or importance to man and his existence. Following from this, they also claim that there is no design or purpose of providence for the human species. This view devaluates man to a level below that on which God places him as his highest creation. Unless our worth is rooted and grounded in something objective and outside ourselves, we are of value only to ourselves and can never rise above the impermanence of our own short lives. God is outside our finite and transitory universe and his love for us gives us a value which transcends not only ourselves but our finite universe as well.

In the world besieged by war, violence, hunger, diseases and general social disorder such as ours, there is no gainsaying the fact that we need courage to keep life going. And that this courage is founded on hope and faith in a loving, caring and faithful God. This is the succor that religion or belief in God brings; and this is not an empty succor. Without such belief or faith, life becomes absurd and meaningless in the face of disappointments, failures and difficulties. This perhaps explains why there are many cases of suicide in many secular (humanist) societies like America than there are in religious societies like Africa (Obioha, 2013). Despite the high level of suffering in Africa, most Africans do not resort to suicide as an ultimate solution. They go through the numerous sufferings and challenges of life with hope, courage, determination and faith that things will get better some day, and sooner or later, things do get better-miracle is a function of belief and faith in God's intervention in the affairs of man. Africans or those who believe in miracles do receive miracles from God for their challenges. There are verifiable cases of miracles amongst Africans and indeed amongst those (anywhere) who believe in God's existence and God's involvement in man's affairs. This is the pragmatic benefit for belief and faith in God.

To Africans and indeed to anyone who believes in God, life is therefore not absurd and meaningless even in the midst of disappointments and difficulties. one thing that is anti-human progress and in fact, anti-human dignity is an attitude of faithlessness, lack of courage and the inability to hold on to life in the face of life challenges. There is nothing dignifying of man to lose courage, faith and hope for the future and then ends one's life either through suicide or euthanasia because of the present challenges of life. But the ability to hold on to the future, even when it appears irrational to do so, is a function of faith in God who is involved in human affairs.

Giving credence to the above submissions, Dukor is of the view that the whole of African philosophy and even that of Indian philosophy is replete with humanism that is theistically colored. It is humanistic because it is centered on man's essence and existence but it is also theistic because it makes a strong reference and link to God who is at the center of man's existence and experiences. Therefore the Indians and indeed the Africans manifest deep faith in God in dealing with their various existential experiences in life both positive and negative. They recognize the fact that God is the authority over the affairs of men. Dukor, writes,

Buddha's historic science about God as the metaphysical entity and supernatural authority in the affairs of men is humanistic ally motivated. On the other hand, the African attitude is that theism or conception of God is a necessary denomination in all human affairs. In Indian philosophy and African philosophy, we find that in a particular sense, these philosophies are humanistic but their humanism is combined with theism (Dukor, 2010: 63-64). 
What Dukor is saying here is that Indian and African philosophies of man is humanistic and at the same time theistic giving their deep rooted faith in the spiritual. He recognizes the fact that this recognition of and acceptance of the spiritual element in man has enabled them to deal with the problem of suffering and have converted same to an advantage unlike their counterparts in heavily atheistic humanistic environments who are easily defeated in the face of suffering. When people are able to face life challenges squarely, it helps them in a way to build capacity for human dignity and well-being. African theistic humanism helps to build this capacity - this confidence and courage that to face life challenges bearing in mind that life, after all, is not meaningless no matter its perceived ups and downs.

The second virtue of African humanism which we noted above is their belief in the fact that their fellow humans are God's images like themselves. African humanism constitutes all human beings into one universal family of mankind created in the image of their father and having the same father God. This idea is expressed by an Akan maxim, "All human beings are children of God; no one is a child of the earth". This claim is based on the belief that there must be something intrinsically valuable in God: the human being considered a child of God, presumably by reason of having been created by God and having in his or her nature some aspect of God, ought also to be held as of intrinsic value, worthy of dignity and respect. The general African belief that human beings are created by God that they are children of God-most probably lies at the base of the values attached to humanity and unity by the African people. And their having a speck of the divine nature (i.e soul) in them constitutes all human beings into one universal family of humankind (Gyekye, 1996). This traditional virtue perhaps explains why there is no history of racism in Africa. Africans are not known for racism unlike their counterparts during the black and ugly days of racism in America and Germany just to mention but a few. Traditionally, Africans are known to be highly hospitable both to themselves and strangers or better put foreigners. This is why the obnoxious xenophobic attacks by some South Africans against other African citizens residing in their country have been widely condemned by many African governments and citizens as being un-African.

Unfortunately, these traditional values of African humanism seem to have taken a flight from Africa possibly as a result of the wind of (negative) change occasioned by globalization and acculturation. Africa today is witnessing series of social unrests and human right abuses. The solution to these problems is not external but internal. Africans have to look inwards and reinvent their traditional values of African humanism to solve our problems for as Nkrumah said many years ago, "our philosophy must find its weapons in the environment and living conditions of the African people" (Nkrumah, 1964:78). When people see others as God's images like themselves and treat them as such, it will reduce all kinds of human (right) abuses, neglect, oppressions, afflictions, marginalization and or outright denials of their entitlements etc. No doubt, these anomalies are what bring about social unrest not only in Africa but in other parts of the world.

\section{Conclusion}

Today Africa is faced with, among other things, challenges of social unrest and human right abuses and therefore seriously and urgently needs a home grown philosophy for social cohesion and human well-being. Having a challenge is really not the problem for every human life and society has its own share of challenges at one point or the other. The real problems are the inability to identity and define the challenge(s) and therefore intellectually seek for holistic and enduring solution(s) to them. In this paper, efforts have been made to identity some of the challenges the African continent is faced with. In response to these challenges, the paper has equally argued that the solution(s) to these challenges are not farfetched as they are embedded in the traditional value of African humanism under its tripod virtues of one, having strong distaste for extreme individualism. Two, favoring and building a community- based society which is conducive for social justice. Third, being ontologically theistic, it brings with it the spiritual dimension that complements and satisfies man's spiritual needs and longings and helps people treat others as God's images like themselves which ultimately helps to reduce societal frictions to the barest minimum.

\section{REFERENCES}

[1] Bell, R. (2002).Understanding African Philosophy. New York: Routledge.

[2] Demarco, D. (2008)."Ubuntu: something our society needs" in Social Justice Review September/ October.

[3] Dukor, M. (2010).Theistic Humanism of African Philosophy. Germany: LAMBERT Academic Publishing. 
[4] Ekei, C. (2001).Justice in communalism. Lagos Realm Communication Ltd.

[5] Ekwuru, G. (1999).The Pangs of an African Culture in Travail Owerri: Totan Publishers Limited.

[6] Gbadegesin, Segun (1991). African Philosophy, Traditional Yoruba Philosophy and Contemporary African Realities. Chicago: Gateway.

[7] Gyekye, Kwame (1987). An Essay on African Philosophical Thought: The Akan Conceptual Scheme. New York: Cambridge University press.

[8] Gyekye, K (1996).African Cultural Values: An Introduction. Ghana: Sanfola Publishing Co.

[9] Gyekye, K. (1997).Tradition and modernity: Philosophical Reflection on the African Experience. Oxford: Oxford University Press.

[10] Iroegbu, Pantaleon (2000). The Political Significance of Belongingness. Journal of Philosophy and Development, 6 (1\&2), 3-17.

[11] Nkrumah, Kwame, (1957).Autobiography of Kwame Nkrumah. London: Panaf Books Ltd.

[12] Nkrumah, K. (1964).Consciencism: Philosophy and ideology for Decolonization and Development with particular Reference to the African Revolution London: Heinemann.

[13] Nyerere, J. (1968).Ujamaa, Essays in solialism Oxford: Oxford University Press.

[14] Obioha, P. (2013)."A Critique of Atheistic Humanism in the Quest for Human Dignity". Open Journal of Philosophy. Vol. 3 (IA) February.

[15] Schmandt, H.J. (1956).Fundamentals of Government. USA: Bruce Publishers.

[16] Wiredu, Kwasi (1983). The Akan Concept of Mind. Ibadan Journal of the Humanities. 3. 15-35.

\section{AUTHORS' BIOGRAPHY}

Dr. Precious Obioha, obtained his PhD from Olabisi Onabanjo University, Ogun State Nigeria in March, 2013. His doctoral thesis, A Thomistico-communal Idea of personhood as a Foundation for Human Well-being, uses the philosophical frameworks of Aquinas and communal perspectives on personhood as a basis for the pursuit of human dignity and well-being. He currently teaches SocioPolitical Philosophy, Ethics, Philosophy of Technology and contemporary issues in philosophy in Akwa Ibom State University. He equally researches on issues of Africa's quest for socio-economic and political renaissance. In this regard, he has written scholarly articles both in international and local academic journals some of which are, "Radical Communitarian Idea of the Human Person in African Philosophical Thought: A Critique" in The Western Journal of Black Studies, Washington State University, Pullman,Washington USA.Vol.38,No.1 Spring,2014;" A Communitarian Understanding of the Human Person as a Philosophical Basis for Human Development "in The Journal of Pan African Studies, California Institute of Pan African Studies, Los Angeles California, USA.Vol.6,No.8, March 2014.Pp.247-267; "A Critique of Atheistic Humanism in the Quest for Human Dignity" in Open Journal of Philosophy, University of Denver,USA.Vol.3,No.1A,2013.Pp.131-139; "African Communal Personhood and Its Implications for Human Well-being" in Journal of Philosophy and Nature". Department of Classics and Philosophy, University of Cape Coast Ghana.Vol.9, Nos.1\&2, 2013.Pp.76-96.

Godwin Okaneme, B.A., M.A., Ph.D (Awka) is a Lecturer in the Department of Philosophy, University of Abuja, Nigeria. He has published articles in several learned journals and books both locally and internationally. He has attended several academic conferences both locally and internationally where he presented papers. He equally serves as a resource person to several media houses in Nigeria. 